\title{
We might need a little anxiety: A finding of the students' problem-solving on fraction operation
}

\author{
Yuli Purwasih, Vita Istihapsari*, Afit Istiandaru \\ Universitas Ahmad Dahlan, J1. Ahmad Yani, Tamanan, Bantul, DIY 55191 Indonesia \\ ${ }^{*}$ Corresponding e-mail: vita.istihapsari@pmat.uad.ac.id
}

\begin{abstract}
One of the factors affecting the students' mathematical problem-solving ability is the mathematics anxiety. It was commonly believed that the higher anxiety a student feels, the lower performance the student does. This research aims to describe the students' problem-solving performance on fraction operation within three levels of mathematics anxiety - the high, the moderate, and the low anxiety. In this research, we selected six subjects by administering a questionnaire. The subjects - representing each of the anxiety levels - engaged in a problem-solving test on fraction operation and then being interviewed about their problem-solving process based on Polya framework. After a number of triangulations and discussions, we found that the students with high anxiety tended to ruin their problem-solving process due to somatic symptoms. We also found that the students with moderate anxiety developed a good care such that the process going well. Interestingly, the students with low anxiety did not carefully solve the problems and made some mistakes in calculation. A simple question might be addressed for future research. Does anxiety sometimes develop a good alert that makes the student careful about their problem-solving steps?
\end{abstract}

Keywords: mathematics anxiety, Polya framework, problem-solving

How to cite: Purwasih, Y., Istihapsari, V., \& Istiandaru, A. (2020). We might need a little anxiety: A finding of the students' problem-solving on fraction operation. International Journal on Education Insight, 1(1), 13-20. DOI: http://dx.doi.org/ijei.v1i1.2316

\section{INTRODUCTION}

Despite the common consideration that problem-solving is an important skill in mathematics learning (Polya, 2004; Hadi \& Radiyatul, 2014), many challenges are faced by mathematics educators to make their students perform well in mathematics problem-solving process (Syafri, 2017; McIntosh et al, 2000). Problem-solving makes the students motivated to seek the solution to reach certain goal (Nurrizbaeni \& Setiawan, 2019). It requires the students' readiness, knowledge, and creativity to deal with daily life problems. To solve the problems, the students need particular steps, one of which refers to Polya.

Polya (2004) said that a problem-solving generally follow certain steps understanding the problem, devising a plan, carrying out the plan, and looking back at the process and the result of the problem-solving. These steps, sometimes, are difficult to see in the students' work if the instrument does not explicitly require them to write the details of the steps. Therefore, if a teacher needs to look at their students' ability to solve problems according to Polya, then the instrument should accommodate the way to see it.

The students' problem-solving ability often face a barrier. One of the barrier is the students' mathematical anxiety. Mathematics anxiety is a students' reactional emotion based on a previous unpleasant experience 
affecting the next learning process (Ansari \& Saleh, 2019). If students get a good learning result, they barely have the mathematics anxiety, and vice versa.

When mathematics anxiety is higher, the ability to solve mathematics problems will be lower (Ramirez et al, 2016). Based on Al Mutawah (2015), the TIMSS data states that there are 55\% of students who feel anxiety in working on mathematics problems, including during the TIMSS test. Mathematics anxiety arises because mathematics is considered a difficult subject as its characteristics that are abstract, requiring logical thinking, having too many symbols and confusing formulas (Syafri, 2017).

Based on an observation we conducted in SMP Muhammadiyah 1 Gamping - a private junior high school in Yogyakarta, Indonesia - on October 2019, we found that many students found difficulties in solving mathematics problems. Most students could not identify what was given in the problem, its objective, and also what formula should be applied. Therefore, the result was not satisfactory. It was only $8.3 \%$ of the students passed the test of mathematics problem-solving.

We also interviewed the mathematics teacher at the school. First, we found that the teacher has never mapped or analyzed the students' problem-solving ability. The teacher understood that there were many forms of error the students did during the problem-solving process, and supported any effort to look at it comprehensively. Second, the teacher has never analyzed the constraint affecting the students' problem-solving ability. In this part, we introduced the mathematics anxiety as it was also found in the students.

Learning from the situation explained above, this research aims to describe the students' mathematics problem-solving ability based on their status of mathematics anxiety - the high, the moderate, and the low anxiety.

\section{RESEARCH METHOD}

This research is qualitative, discussing about the problem-solving ability performed by the $7^{\text {th }}$ grade students of SMP Muhammadiyah 1 Gamping, a private junior high school in Yogyakarta, Indonesia, based on their level of mathematics anxiety. At first, we administered a mathematics anxiety questionnaire to a classroom consisted of 25 students. The classroom was quite diverse in terms of gender and economic background. The students were all Javanese and quite good at communication. The questionnaire assessed the anxiety in three aspects - the somatic, cognitive, and attitude. From the result of the questionnaire, we selected six students representing the high, moderate, and low levels of anxiety, two students in each category. We also consulted the selection of the subjects to the teacher in order to get subjects who can communicate their thought well.

Further, we gathered the subjects and administered a problem-solving test on fraction material. The test tried to look at the process of problem-solving according to Polya, which consists of some steps required - understanding the problem, devising a plan, carrying out the plan, and looking back at the process and result. After analyzing the test results, we conducted some interviews to the subjects to get a deeper understanding about the process and the results of problem-solving. To get a valid finding, we triangulated the findings from the test and the interviews using a method triangulation. The findings were then discussed and concluded. 


\section{RESULTS AND DISCUSSION}

We presented the findings based on the level of mathematics anxiety as follows.

\section{The problem-solving ability of students with high level anxiety}

Two students - Subject 1 and Subject 2 - had a high level of mathematics anxiety. Both subjects reported that they often get a headache before or during mathematics class, and it gets worse during mathematics exam. Since the somatic symptoms appears, it was indicated that they have a high level of anxiety. Moreover, both subjects were so afraid to ask questions or to perform their work in front of the class. However, they also have a good curiosity and willing to study hard in mathematics.

In the problem-solving test, which consisted of four problems, Subject 1 successfully solved two of them. In all problems, Subject 1 could not show the step of devising a plan. One of the solution is presented in Figure 1.

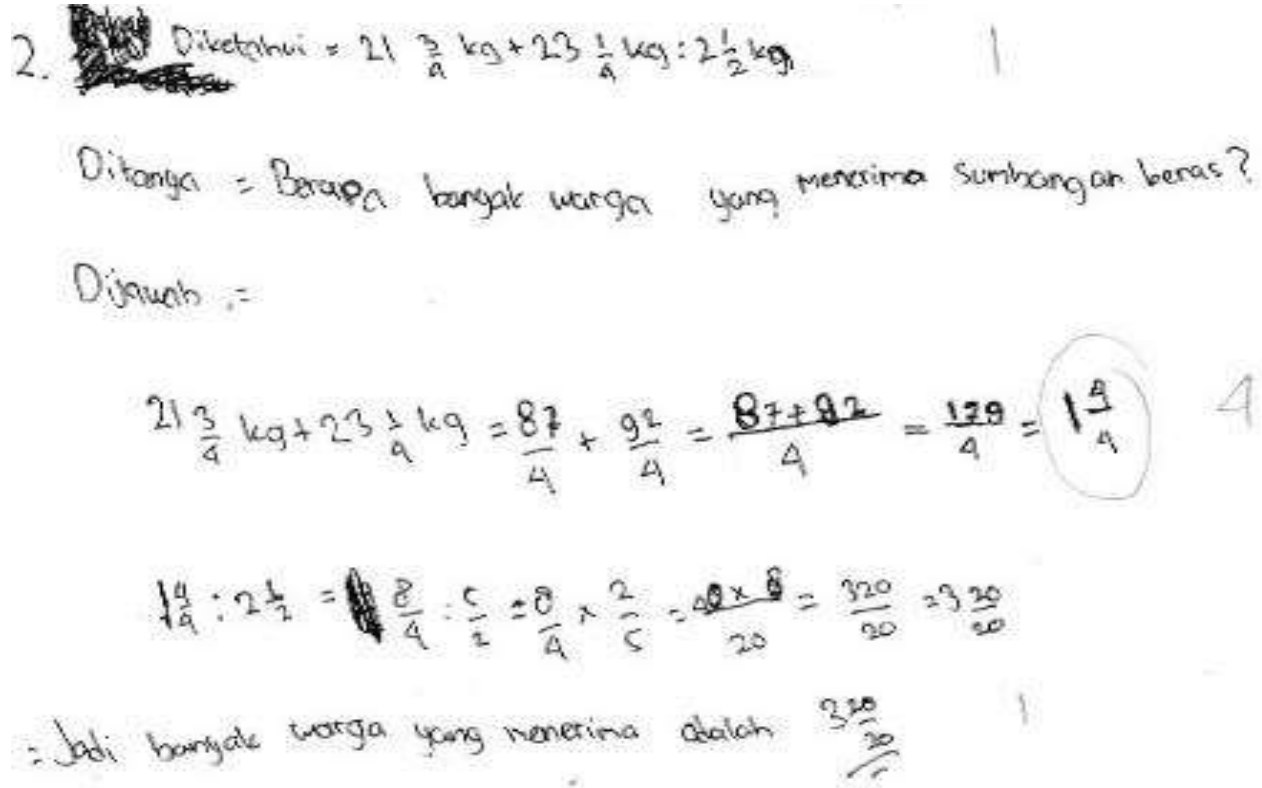

Figure 1. Subject 1's answer to the Problem 2

In Figure 1, Subject 1 wrote what's given in the problem and its objective. However, Subject 1 did not write the strategy to solve it as requested by the problem. We should know why Subject 1 add up the fraction and the meaning of the operation carried out. Finally, Subject 1 made a mistake of converting the mixed fraction to common fraction. Thus, it arrived at an inappropriate answer.

During the interview session, Subject 1 confirmed that his heart beat so fast and sometimes he was afraid that the answer was going to be wrong. Subject 1 encountered a problem of simplifying fraction with a big number of numerator.

Now, let's take a look at Subject 2's work as presented in Figure 2. 


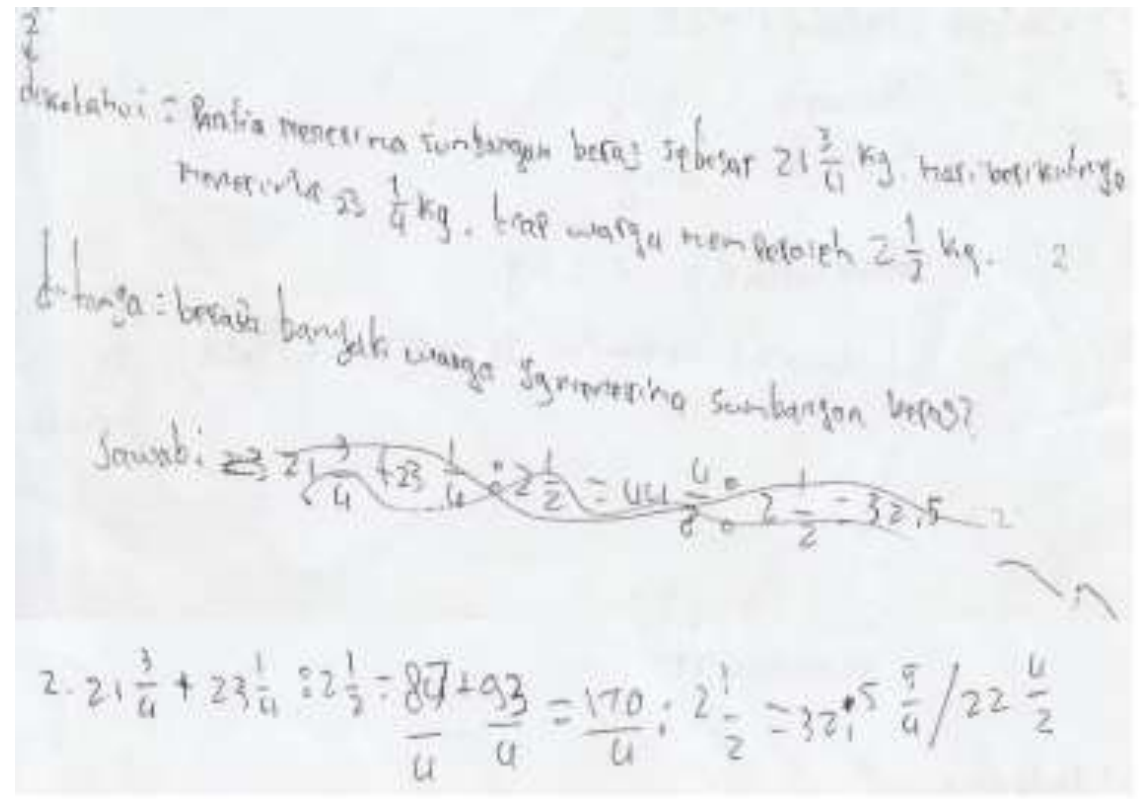

Figure 2. Subject 2's answer to the Problem 2

Similar to Subject 1 , it was simple to write down what was given and the objective of the problem. However, Subject 2 did not provide the strategy to solve the problem as requested. Subject 2 successfully converted mixed fraction into common fraction, but failed to do an addition. Therefore, the result was also wrong. There was no conclusion written at the answer sheet and we could not sure if Subject 2 conducted a check to the answer.

In the interview session, Subject 2 confirmed that the problem was difficult. He was not sure how to solve the problem, and therefore, his mind went blank and arrived at a wrong solution. Finally, Subject 2 said that he is run out of time in working with the problem.

The students with high level of anxiety tend to have a somatic symptom, such as nausea, sweaty, trembling, heart beating fast, or headache (Wicaksono $\&$ Saufi, 2013). These condition distracts the students to think clearly, and therefore, students often run out of time and carelessly make mistakes. Factors affecting the students' failure in problem-solving are working in a rush, careless, failed to understand the problem, and failed to understand the mathematics material (Amalia, 2017). Overall, the subjects with high level of anxiety could do the Polya steps but not complete, i.e. understanding the problem, devising a plan, carrying out the plan, making a conclusion without checking the process and he answer.

\section{The problem-solving ability of students with moderate level anxiety}

Subject 3 and Subject 4 were two students represented the moderate level of mathematics anxiety. Both of them confirmed that they were afraid with mathematics lesson because they were so shy if their friend know that they could manage to solve the challenges given by the teacher. Most of anxiety aspects shown by Subject 3 and Subject 4 were cognitive.

The Subject 3's work on problem-solving test is presented in Figure 3. 




Figure 3. Subject 3's answer to the Problem 3

In the stage of understanding problem, Subject 3 could write down what was given and the objective of the problem completely. Though Subject 3 did not write the strategy of problem-solving, it was confirmed during the interview session that Subject 3 tried to sum up the amount of the flour and then divided it into the package unit, therefore, the number of group received the package could be determined. Subject 3 also successfully calculated the result and worked with faction operation. Finally, Subject 3 wrote the conclusion and confirmed in the interview session that she checked twice the result of the calculation.

The next, let's take a look at the work of Subject 4, as presented in Figure 4.



Figure 4. Subject 4's answer to the Problem 3

In the stage of understanding problem, Subject 4 could write down what was given and the objective of the problem completely. Though Subject 3 did not write the strategy of problem-solving, it was confirmed during the interview session that Subject 4 tried to sum up the amount of the flour and then divided it into the package unit, therefore, the number of group received the package could be determined. Subject 4 also successfully converted the mixed fraction

We might need a little anxiety: A finding of the students' problem-solving on fraction Purwasih, Istihapsari, \& Istiandaru 
to common fraction and worked with faction operation. Finally, Subject 4 wrote the conclusion and confirmed in the interview session that she checked twice the result of the calculation.

Interestingly, both subjects in moderate level of anxiety had more awareness and carefulness to deal with problems, as they checked the results twice and three times in the other problems. In terms of the mathematics anxiety, Subject 3 and Subject 4 were afraid of being not able to compete with the other friends. They were afraid that people think they are incapable. But in the problem-solving, they were more careful by checking the result multiple times. Thus, the results tended to be correct.

According to some research, students with a moderate anxiety are usually afraid of inability to compete with others. It is bad that it could affect the students' performance in problem-solving (Hidayat, 2018; Amalia, 2017). However, the finding in this research tends to be different. With a little anxiety, students have a little fear of failure. Thus, they will struggle more and be careful. Though it is not for a generalization purpose, but this different finding could be possible to happen in different case with a measured and controlled anxiety.

\section{The problem-solving ability of students with low level anxiety}

In this level of anxiety, we had Subject 5 and Subject 6 as the representative. Both of them had a good communication skill, were not afraid of mathematics lesson. Sometimes, they were afraid of getting bad score, but they believe by learning hard, they could manage to achieve it.

The work of Subject 5 is presented in Figure 5 .

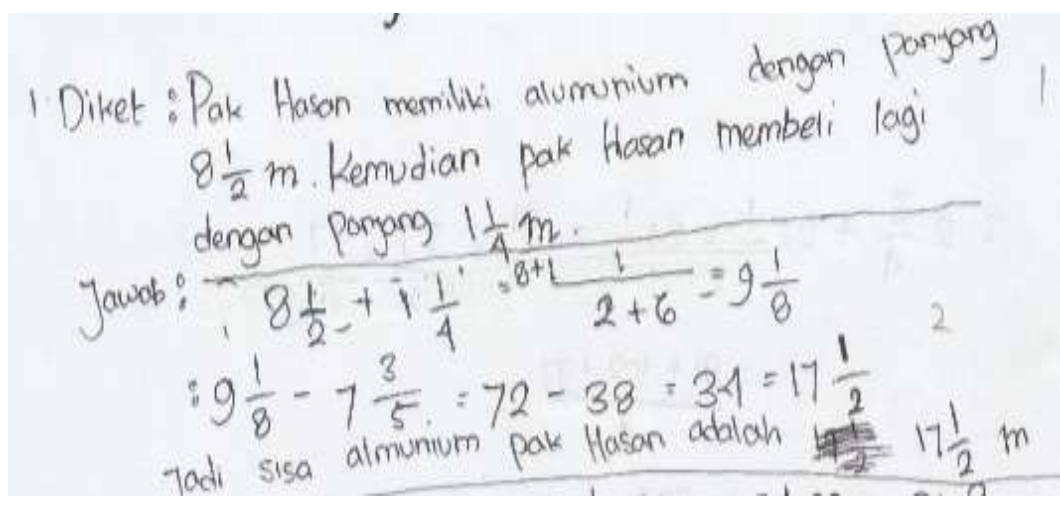

Figure 5. Subject 5' s answer to the Problem 1

In the stage of understanding the problem, Subject 5 could write the given condition and the objective, but some information as missing, which means that Subject 5 was not careful enough to understand the problem. In the stage of devising a plan, Subject 5 did not provide any written and detailed strategy. Then, Subject 5 execute the problem-solving process not by converting the mixed fraction to common fraction. Subject 5 directly add the fractions and made a mistake in determining the least common multiple as the denominator. Therefore, it arrived a wrong result. Finally, in the last step, Subject 5 could make a conclusion though the calculation was wrong.

Further, the work of Subject 6 is presented in Figure 6. 


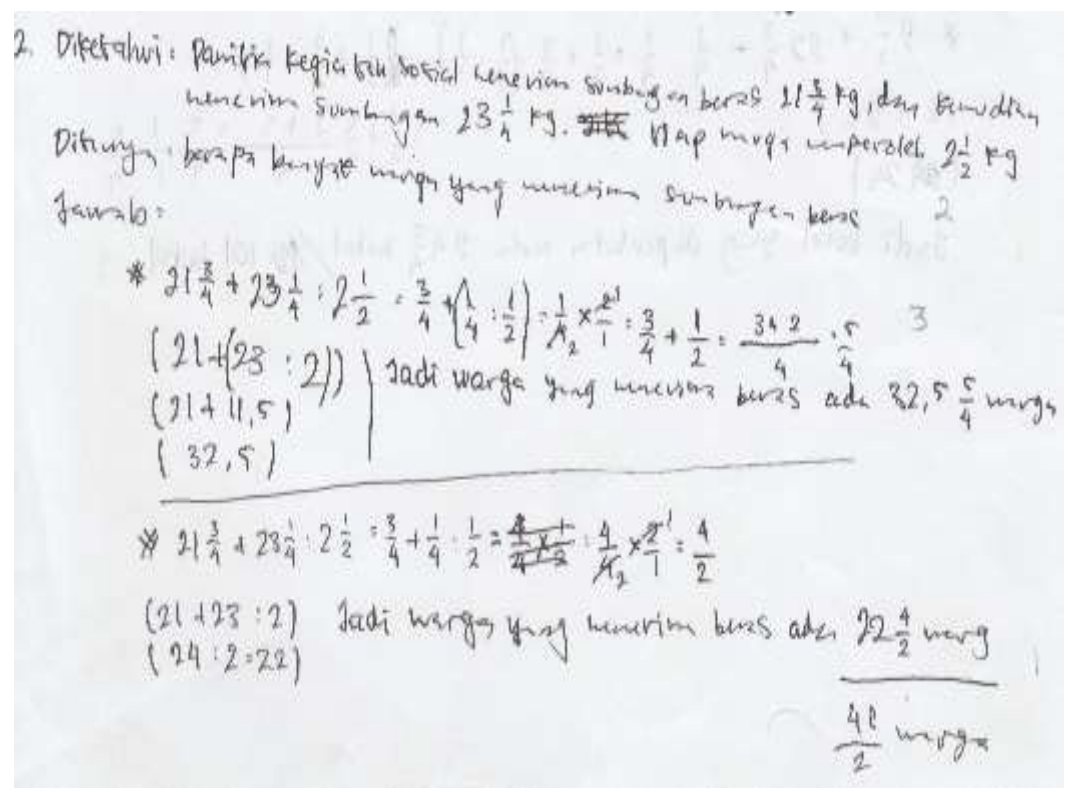

Figure 6. Subject 6's answer to the Problem 1

In the stage of understanding problem, Subject 6 could write what was given and the objective of the problem completely. Thus, Subject 6 could understand the problem well. However, Subject 6 did not provide any written and detailed strategy. At first, Subject 6 did not convert mixed fraction to common fraction. Subject 6 directly calculated the whole number part with the whole number part and the fraction part with the fraction part. The calculation is correct, but it should be added first before divided. Therefore, we can see that Subject 6 was able to do the fraction operation but was not careful enough to arrive at a correct solution. At the end, Subject 6 could make a conclusion though the calculation was wrong.

Based on the finding, we could see that subjects with low anxiety could enjoy the learning and calm during the learning process. However, this situation made them careless. They lost control and did not look back at the process and the result of the problem-solving. It is also a little bit different with many studies who suggest that the less anxiety, the higher learning achievement. But, if the students are careless, then low anxiety could not help them to stand in mathematics lesson.

\section{CONCLUSION}

It is commonly known that mathematics anxiety distracts the students' performance in mathematics learning - the higher anxiety, the lower achievement. The finding of this research might be slightly different. In the high level of anxiety, students indeed messed up their problem solving steps. They made fallacies in calculation, did not understand what was given and what was demanded by the problem, as well as could not tell the strategy used to solve problems.

However, the students with low level of anxiety tend to make the problem easy, which makes them not careful enough to look back at the process and the result of problem-solving. In this situation, low anxiety could not help them to stand in mathematics lesson if they lost control in performing problem-solving.

Finally, the highest achievement goes to the subjects with moderate level of anxiety. With a little anxiety, students have a little fear of failure. Thus,

We might need a little anxiety: A finding of the students' problem-solving on fraction Purwasih, Istihapsari, \& Istiandaru 
they will struggle more and be careful. Though it is not for a generalization purpose, but this different finding could be possible to happen in different case with a measured and controlled anxiety.

\section{ACKNOWLEDGEMENT}

We thank the principal, teachers, and students of SMP Muhammadiyah 1 Gamping, Sleman, Yogyakarta who actively contributed in this research.

\section{REFERENCES}

Amalia, S. R. (2017). Analisis kesalahan berdasarkan prosedur Newman dalam menyelesaikan soal cerita ditinjau dari gaya kognitif mahasiswa. AKSIOMA: Jurnal Matematika dan Pendidikan Matematika, 8(1), 17-30.

Al Mutawah, M. A. (2015). The influence of mathematics anxiety in middle and high school students math achievement. International Education Studies, 8(11), 239-252.

Ansari, B. I., \& Saleh, M. (2019). Pengaruh collaborative teaching dan pengetahuan awal terhadap kecemasan matematis siswa. JIPMat, 4(2).

Hadi, S., \& Radiyatul, R. (2014). Metode pemecahan masalah menurut polya untuk mengembangkan kemampuan siswa dalam pemecahan masalah matematis di sekolah menengah pertama. EDU-MAT: Jurnal Pendidikan Matematika, 2(1), 53-61.

Hidayat, R. (2018). Kontribusi mathematics anxiety terhadap kemampuan akademik mahasiswa pada pembelajaran kalkulus. JNPM (Jurnal Nasional Pendidikan Matematika), 2(2), 206-216.

McIntosh, R., Jarrett, D., \& Peixotto, K. (2000). Teaching mathematical problem solving: Implementing the vision. Retrieved from: http://citeseerx.ist.psu.edu/viewdoc/download?doi=10.1.1.113.1169\&re $\mathrm{p}=$ rep $1 \&$ type $=$ pdf.

Nurrizbaeni, N., \& Setiawan, W. (2019). Analisis kemampuan pemecahan masalah matematik siswa kelas $X$ pada materi persamaan dan pertidaksamaan nilai mutlak. Journal on Education, 1(3), 327-336.

Polya, G. (2004). How to solve it: A new aspect of mathematical method (Vol. 85). Princeton University Press.

Ramirez, G., Chang, H., Maloney, E. A., Levine, S. C., \& Beilock, S. L. (2016). On the relationship between math anxiety and math achievement in early elementary school: The role of problem solving strategies. Journal of experimental child psychology, 141, 83-100.

Syafri, F. S. (2017). Ada Apa dengan Kecemasan Matematika?. Journal of Medives: Journal of Mathematics Education IKIP Veteran Semarang, 1(1), 59-65.

Wicaksono, A. B., \& Saufi, M. (2013). Mengelola kecemasan siswa dalam pembelajaran matematika. In Prosiding Seminar Nasional Matematika dan Pendidikan Matematika (Vol. 9). 